\title{
Wieloletnia prognoza finansowa jako instrument skutecznego zarządzania dtugiem jednostki samorządu terytorialnego
}

\section{Wprowadzenie}

Ustawa z 27 sierpnia 2009 r. o finansach publicznych ${ }^{1}$ (ufp) wprowadziła do systemu prawnego nową instytucję - wieloletnią prognozę finansową (WPF). Prognoza miała stanowić dla samorządu terytorialnego wartość dodaną w zakresie planowania wieloletniego, w tym także w odniesieniu do procesów związanych z zaciąganiem długu. Jednocześnie ustawodawca postanowił w sposób istotny zmienić instrumenty monitorowania i ograniczania zadłużenia jednostek samorządu terytorialnego (JST), wprowadzając w art. 243 ufp - obliczaną odrębnie dla każdej jednostki samorządowej - relację spłaty zobowiązań ${ }^{2}$. Spełnienie relacji warunkuje możliwość uchwalenia budżetu i prognozy finansowej.

Wejście w życie przepisów ustawy korespondowało ze wzrostem zadłużenia JST, które z kwoty 25875941 tys. zł - wg stanu na dzień 31 grudnia 2007 roku ${ }^{3}$ - wzrosło do kwoty 40294344 tys. zł - wg stanu na dzień 31 grudnia $2009 \mathrm{roku}^{4}$. Tendencja wzrostowa utrzymała się przez następne lata, a kwota długu JST wg stanu na dzień 31 grudnia 2014 roku

1 Ustawa z 27.8.2009 r. o finansach publicznych (t.j. Dz.U. z 2013 r., poz. 885 ze ).

2 Przepis art. 243 ufp miał zastosowanie do budżetów JST poczynając od 2014 roku.

3 Sprawozdanie z działalności regionalnych izb obrachunkowych i wykonania budżetu przez jednostki samorzqdu terytorialnego w 2007 r., KR RIO, Warszawa 2008 r., s. 149.

4 Sprawozdanie z działalności regionalnych izb obrachunkowych i wykonania budżetu przez jednostki samorzqdu terytorialnego w 2009 r., KR RIO, Warszawa 2010 r., s. 147. 
wynosi 72109871 tys. zł․ Utrzymujący się wysoki poziom zadłużenia JST podkreśla znaczenie WPF, jako instrumentu zarządzania gospodarką finansową JST w sytuacji zaciągania zobowiązań dłużnych, podlegających spłacie często w okresie kilku lub kilkunastu lat. Czy jednak obecna konstrukcja przepisów określających kształt prognozy, jak również przepisów normujących reguły zaciągania zobowiązań dłużnych pozwala na wykorzystanie WPF jako skutecznego instrumentu zarządzania długiem JST? Niestety, odpowiedź na tak zadane pytanie nie jest pozytywna.

\section{Prognoza kwoty długu i jego spłaty}

Jedną z części WPF jest prognoza długu, w której jednostka samorządowa prezentuje kwotę długu, sposób sfinansowania jego spłaty oraz relacje, o których mowa w art. 242-244 ufp, w tym informację o stopniu niezachowania tych relacji w przypadkach, o których mowa w art. 240a ust. 4 i 8 i w art. $240 \mathrm{~b}$ ww. ustawy.

Prognozę długu tworzy zespół parametrów finansowych i obliczanych na ich podstawie wskaźników ${ }^{6}$, dla okresu, na jaki przyjmowana jest prognoza. W literaturze powszechna jest opinia, iż prognoza kwoty długu ma największe znaczenie dla treści WPF ${ }^{7}$. Prognoza ma w szczególności potwierdzić, że jednostka samorządowa zachowuje relację spłaty zobowiązań określoną w art. 243 ust. 1 ufp. Relacja ta jest aktualnie najważniejszym instrumentem normatywnym pozwalającym monitorować i ograniczać zadłużenie JST. Z uwagi na powyższe, wartość prognozy długu powinna być oceniona przez pryzmat skuteczności wskazanego mechanizmu, o czym w dalszej części artykułu.

5 Sprawozdanie z działalności regionalnych izb obrachunkowych i wykonania budżetu przez jednostki samorzq̨du terytorialnego w 2014 r., KR RIO, Warszawa 2015 r., s. 153.

6 Istotne znaczenie dla prognozy długu mają także określone wartości finansowe sprzed roku bazowego, z uwagi na konstrukcję relacji spłaty zobowiązań, ujętą w art. 243 ustawy o finansach publicznych.

$7 \mathrm{~S}$. Srocki, Wieloletnia prognoza finansowa jako instrument stabilizacji finansowej samorzqdu - zagadnienia prawne, „Finanse Komunalne” 2014, nr 12, s. 9; J.M. Salachna, Budżet i wieloletnia prognoza finansowa jednostek samorzqdu terytorialnego. Od projektu do sprawozdania, Gdańsk 2010 r., s. 31; P. Walczak, Wskaźnik spłaty zobowiqzań - art. 243 ustawy o finansach publicznych, [w:] Zadłużenie jednostek samorządu terytorialnego. Wyzwania w obliczu nowej perspektywy finansowej UE, red. P. Walczak, Warszawa 2014 r., s. 67-68. 
Prognoza kwoty długu obejmuje okres, na który zaciągnięto oraz planuje się zaciągnąć zobowiązania. Aktualne przy tym pozostaje pytanie, jak należy rozumieć sformułowanie „planuje się zaciągnąć”. Czy zamiar zaciągnięcia zobowiązań wyrażony w tym przepisie dotyczy wyłącznie zobowiązań z roku bazowego (czyli roku budżetowego), czy też także tych pokazanych w kolejnych latach, jako źródło pokrycia prognozowanego $\mathrm{w}$ WPF deficytu budżetu JST? Użycie przez ustawodawcę pojęcia "planuje się" stanowi argument za poglądem, że w rozważanej normie prawnej chodzi o rok budżetowy, w którego zakresie uchwała budżetowa zawiera normy planistyczne realizowane na etapie jego wykonania - rok bazowy ${ }^{8}$.

\section{Funkcja prognozy kwoty długu}

Jak już wspomniano, zasadniczą funkcją prognozy kwoty długu jest potwierdzenie spełnienia przez JST relacji spłaty zobowiązań, mającej swoje prawne umocowanie w art. 243 ust.1 ufp. Potwierdzenie to rozciąga się na cały okres, na jaki jest uchwalona prognoza. Niezachowanie przedmiotowej relacji w jednym $\mathrm{z}$ lat budżetowych objętych prognozą jest istotnym naruszeniem prawa, skutkującym nieważnością uchwały w sprawie WPF i wszczęciem postępowania nadzorczego w stosunku do uchwały budżetowej ${ }^{9}$. Omawiany instrument nie ma znaczenia wyłącznie formalnego, jak każda regulacja prawna ma za sobą potrzebę ochrony określonych wartości, co uzasadnia ingerencję ustawodawcy w daną sferę życia społecznego. Zaciąganie długu, oprócz aspektów pozytywnych związanych przede wszystkim z przyśpieszeniem realizacji procesów inwestycyjnych poprawiających jakość infrastruktury technicznej i społecznej samorządu terytorialnego, może prowadzić także do pojawienia się negatywnych zjawisk w zakresie gospodarki finansowej.

Nadmierne zadłużenie w skrajnym wypadku może doprowadzić do utraty płynności finansowej przez jednostkę samorządową oraz do niemożności wykonywania zadań publicznych. Relacja spłaty zobowiązań ma w swoim założeniu chronić JST przed sytuacją zaciągnięcia długu,

8 Tak też W. Lachiewicz, [w:] Finanse publiczne. Praktyka stosowania nowej ustawy o finansach publicznych i aktów wykonawczych, red. W. Lachiewicz, Warszawa 2010 r., s. 403-404.

9 Właściwym organem nadzoru w powyższym zakresie jest kolegium regionalnej izby obrachunkowej (zob. art. 11 ust.1 pkt 2 i 7 ustawy z 7.10.1992 r., o regionalnych izbach obrachunkowych - t.j. Dz.U. z 2012 r., poz. 1113 ze zm.). 
którego poziom spłaty przekroczy wyznaczoną przez ustawodawcę granicę. Zapewnia tym samym, wciąż według założeń, bezpieczeństwo finansowe JST i gwarantuje niezakłócone wykonywanie zadań na rzecz wspólnoty lokalnej. W tej perspektywie wniosek o dużym znaczeniu prognozy kwoty długu, jako instrumentu zarządzania długiem ${ }^{10}$, jest $\mathrm{w}$ pełni uzasadniony, tak samo jak konieczność przestrzegania przez JST wymogu realistyczności $\mathrm{w}$ zakresie prognozowania wartości finansowych. Problem pojawia się w momencie, w którym analiza stanu prawnego prowadzi do wniosku, iż wprowadzony przez ustawodawcę mechanizm oddziaływania na zadłużenie JST ma istotne wady, a jego stosowanie w niewystarczającym stopniu zachowuje związek z sytuacją finansową jednostek samorządowych, jak również kwotą długu i poziomem spłaty. $\mathrm{W}$ ten sposób problemy związane $\mathrm{z}$ relacją spłaty zobowiązań, przekładają się na prognozę długu, dla której relacja ta ma zasadnicze znaczenie.

\section{Relacja spłaty zobowiązań}

Dla dalszych rozważań niezbędne jest przypomnienie, że stosownie do art. 243 ust. 1 ufp, organ stanowiący JST nie może uchwalić budżetu, którego realizacja spowoduje, że w roku budżetowym oraz w każdym roku następującym po roku budżetowym relacja łącznej kwoty przypadających w danym roku budżetowym:

1) spłat rat kredytów i pożyczek, o których mowa w art. 89 ust. 1 pkt 2-4 oraz art. 90 ufp wraz z należnymi w danym roku odsetkami od kredytów i pożyczek, o których mowa w art. 89 ust. 1 i art. 90 ww. ustawy,

2) wykupów papierów wartościowych emitowanych na cele określone w art. 89 ust. 1 pkt $2-4$ oraz art. 90 ufp wraz z należnymi odsetkami i dyskontem od papierów wartościowych emitowanych na cele określone w art. 89 ust. 1 i art. 90 ustawy,

3) potencjalnych spłat kwot wynikających $z$ udzielonych poręczeń oraz gwarancji do planowanych dochodów ogółem budżetu przekroczy średnią arytmetyczną z obliczonych dla ostatnich trzech lat relacji jej

10 G. Wróblewska za główne cele zarządzania długiem uważa: zaspokojenie popytu JST na pieniądz, minimalizację ryzyka finansowego, minimalizację kosztów związanych z wykorzystaniem długu przez JST, minimalizację ryzyka utraty płynności, skoordynowanie bieżącej i przyszłej zapadalności instrumentów budżetu z wymagalnością zobowiązań, G. Wróblewska, Zarządzanie długiem jednostki samorządu terytorialnego - problemy praktyczne, „Finanse Komunalne” 2015, nr 1-2, s. 99-100. 
dochodów bieżących, powiększonych o dochody ze sprzedaży majątku oraz pomniejszonych o wydatki bieżące, do dochodów ogółem budże$\mathrm{tu}$, ustaloną według wzoru zawartego w omawianym przepisie.

Relacja określona w art. 243 ust. 1 ufp nawiązuje w swojej konstrukcji do limitu mającego swoje oparcie w art. 169 ustawy z 30.6.2005 r. o finansach publicznych ${ }^{11}$, jednak zasadniczo odrębnie określa obowiązującą w danym roku budżetowym granicę spłat. Uniwersalny wskaźnik wyrażony wartością $15 \%$ zastąpiony został indywidualnym dla każdej JST maksymalnym wskaźnikiem spłaty, obliczanym na podstawie wskazanych przez ustawodawcę parametrów finansowych budżetów z ostatnich trzech lat, poprzedzających rok, dla którego ustalany jest pułap spłaty zobowiązań.

Omawiany wskaźnik ogranicza poziom przypadających w danym roku spłat z tytułów wymienionych przez ustawodawcę, nie limituje natomiast wielkości długu JST. Dług ten, przy odpowiednio ułożonym harmonogramie spłaty kredytów i pożyczek oraz wykupu wyemitowanych papierów wartościowych, może osiągnąć wysokie wartości, przekraczające - mającą do 31 grudnia 2013 r. prawne znaczenie - granicę 60\% wykonanych na koniec roku dochodów budżetu JST ${ }^{12}$.

Ograniczenia $\mathrm{w}$ zakresie wysokości spłaty określonych zobowiązań (w tym dłużnych) pośrednio oddziałują na poziom długu, chociaż mogą także skutkować jego zaciąganiem na niekorzystnych warunkach. Przykładowo, na długie okresy, ze spłatą długu w dwóch, trzech ostatnich latach obowiązywania umowy i oczywiście koniecznością ponoszenia wysokich kosztów obsługi zadłużenia $\mathrm{z}$ uwagi na niezmienną przez wiele lat kwotę należności głównej. Presja związana z pozyskaniem środków europejskich, cyklicznością wyborów samorządowych, a także koniecznością kontynuowania rozpoczętych projektów inwestycyjnych zwiększa ryzyko zaciągania zobowiązań dłużnych na warunkach, których ocena może dotykać kwestii gospodarności podejmowanych przez organy JST decyzji. Coraz wyraźniej materializuje się ryzyko, iż stosowanie art. 243 ufp nie tylko nie ogranicza skutecznie wzrostu poziomu zadłużenia JST, ale przyczynia się do zwiększenia kosztów związanych z pozyskaniem środków zwrotnych, a także do powszechnego „rolowania” długu na coraz mniej korzystnych warunkach.

Jak już wskazano, ustawodawca, przyjmując konstrukcję limitującą spłaty zobowiązań wyrażoną w art. 243 ufp, odszedł od funkcjonującej przez

11 Ustawa z 30 czerwca 2005 r. o finansach publicznych (Dz.U. Nr 249, poz. 2104 ze zm.).

12 Zgodnie z art. 170 ust. 1 ustawy z 30 czerwca 2005 r. o finansach publicznych łączna kwota długu jednostki samorządu terytorialnego na koniec roku budżetowego nie mogła przekroczyć $60 \%$ wykonanych dochodów ogółem tej jednostki w tym roku budżetowym. 
wiele lat formuły sztywnego wskaźnika stosowanego przez wszystkie JST. Nowa formuła, w ramach której wyznaczana jest granica możliwych do zaplanowania spłat $\mathrm{z}$ tytułu wskazanych $\mathrm{w}$ ww. przepisie zobowiązań w roku budżetowym, oparta jest na kategorii nadwyżki operacyjnej, która - w ocenie ustawodawcy - w sposób bardzo znaczący charakteryzuje sytuację finansową JST. Aby zapewnić większą miarodajność uzyskanego wyniku, ustawodawca zdecydował, że do obliczenia zdolności JST do spłaty zobowiązań przyjmowane są dane z trzech lat poprzedzających rok budżetowy, dla którego ustalany jest maksymalny wskaźnik spłat.

Decyzja ustawodawcy wyróżniająca kategorię nadwyżki operacyjnej, jako istotną dla obliczenia maksymalnego limitu spłat zobowiązań, ma oczywiście charakter pewnej arbitralności, bowiem wskaźników opisujących sytuację finansową i ekonomiczną JST, w tym jej zdolność do regulowania zobowiązań, jest dużo więcej. Nadwyżka operacyjna określa stosunek dochodów bieżących do wydatków bieżących, będąc także identyfikowana jako wynik operacyjny budżetu. Nadwyżka operacyjna powiększona o dochody ze sprzedaży majątku określa, na gruncie art. 243 ww. ustawy, potencjał JST i jej zdolność do regulowania zobowiązań. Przy czym w celu zachowania stosownych proporcji dla ustawodawcy - w ramach przedmiotowej konstrukcji - nie miała znaczenia kwota nadwyżki powiększonej o wskazane dochody, ale odniesienie tej wartości do dochodów ogółem budżetu JST.

Mając na uwadze zarysowaną powyżej korelację między prognozą kwoty długu a relacją spłaty zobowiązań, zwrócić należy uwagę na dwa kluczowe problemy utrudniające, czy nawet uniemożliwiające, postrzeganie WPF, jako skutecznego instrumentu zarządzania długiem.

\section{Dług spłacany wydatkami}

Z uwagi na okoliczność, że prognoza kwoty długu potwierdza spełnienie relacji spłaty zobowiązań, o której mowa w art. 243 ust. 1 ufp, poza zakresem zainteresowania ustawodawcy pozostają te zobowiązania dłużne, które nie są ujęte $\mathrm{w}$ formule matematycznej określającej przedmiotową relację (ujęte są $\mathrm{w}$ niej natomiast te, które zostały wymienione w art. 89 ust.1 pkt $2-4$ i w art. 90 ww. ustawy $)^{13}$.

13 Czyli pożyczki, kredyty i papiery wartościowe zaciągane (emitowane) na sfinansowanie planowanego deficytu; spłatę wcześniej zaciągniętych zobowiązań; wyprzedzające finansowanie działań finansowanych ze środków budżetu UE oraz 
Na gruncie przepisów o finansach publicznych, w szczególności $₫ 3$ pkt 2 rozporządzenia Ministra Finansów z 28 grudnia 2011 r. w sprawie szczegółowego sposobu klasyfikacji tytułów dłużnych zaliczanych do państwowego długu publicznego ${ }^{14}$ - do kategorii pożyczek i kredytów zalicza się umowy o partnerstwie publiczno-prywatnym, które mają wpływ na poziom długu publicznego ${ }^{15}$; umowy sprzedaży, w których cena jest płatna $\mathrm{w}$ ratach; umowy leasingu zawarte $\mathrm{z}$ producentem lub finansującym, w których ryzyko i korzyści z tytułu własności są przeniesione na korzystającego z rzeczy; a także umowy nienazwane o terminie zapłaty dłuższym niż rok, związane $z$ finansowaniem usług, dostaw, robót budowlanych, które wywołują skutki ekonomiczne podobne do umowy pożyczki lub kredytu.

W żadnym z ww. przypadków JST nie jest ograniczona limitem zaciągania zobowiązań dłużnych ustalanym $\mathrm{w}$ uchwale budżetowej na podstawie art. 91 ust. $1 \mathrm{w}$ zw. $\mathrm{z}$ art. 212 ust. 2 pkt 6 ufp, nie jest związana katalogiem sytuacji wymienionych w art. 89 ust. 1 i art. 90 ww. ustawy, pozwalających na zaciągnięcie określonych zobowiązań dłużnych; nie jest także zobowiązana do uzyskania opinii RIO w sprawie możliwości spłaty długu. Przedmiotowe zobowiązania tworzą dług, nie wywołują jednak zainteresowania prawodawcy, który pozostawia je poza prawną reglamentacją dotyczącą zagadnień związanych z długiem JST. Wyjaśnienie zasygnalizowanej sytuacji nie jest zadaniem prostym, mając na względzie okoliczność, że omawiane zobowiązania stanowią bardzo często analogiczne obciążenie dla budżetów JST, jak zobowiązania dłużne wymienione w art. $89 \mathrm{i}$ w art. 90 ufp, na co wskazał sam prawodawca zaliczając do długu, m.in., umowy nienazwane o terminie zapłaty dłuższym niż rok, związane $\mathrm{z}$ finansowaniem usług, dostaw, robót budowlanych, które wywołują skutki ekonomiczne podobne do umowy pożyczki lub kredytu.

pożyczki z państwowych funduszy celowych przeznaczone na inwestycje lub zakupy inwestycyjne związane z realizacją przedsięwzięć ujętych w uchwale w sprawie WPF.

14 Rozporządzenie Ministra Finansów z 28 grudnia 2011 r. w sprawie szczegółowego sposobu klasyfikacji tytułów dłużnych zaliczanych do państwowego długu publicznego (Dz.U. Nr 298, poz. 1767).

15 Zgodnie z art. 18a ust.1 ustawy z 19 grudnia 2008 r. o partnerstwie publiczno-prywatnym (Dz.U. z 2009 r. Nr 19, poz. 100 ze zm.) - zobowiązania wynikające z umów o partnerstwie publiczno-prywatnym nie wpływają na poziom państwowego długu publicznego oraz deficyt sektora finansów publicznych w sytuacji, gdy partner prywatny ponosi większość ryzyka budowy oraz większość ryzyka dostępności lub ryzyka popytu - z uwzględnieniem wpływu na wymienione ryzyka czynników takich jak gwarancje i finansowanie przez partnera publicznego oraz alokacja aktywów po zakończeniu trwania umowy. 
Zobowiązania uznane za komponenty długu publicznego na podstawie przepisów powołanego rozporządzenia identyfikowane są jako dług spłacany wydatkami, co nie dotyczy tylko - objętych dyspozycją $\$ 3$ pkt 2 ww. rozporządzenia - papierów wartościowych, których zbywalność jest ograniczona. Uzasadnienia dla powyższej terminologii należy szukać w przyjętej przez prawodawcę charakterystyce omawianych instrumentów, która zakładała, że do długu należy wliczyć te umowy, które generują wieloletnie zobowiązania dla JST, nie są jednak związane z pozyskaniem środków finansowych, tak jak ma to miejsce w przypadku papierów wartościowych, pożyczek lub kredytów. W sytuacji np. leasingu lub sprzedaży z ceną rozłożoną na raty JST nie pozyskuje środków finansowych, natomiast w ramach danej instytucji prawnej zobowiązuje się do spełniania świadczeń finansowych w ustalonym okresie, często z obciążeniem budżetów lat kolejnych. Jeżeli w zakresie danych stosunków prawnych ma miejsce udzielenie kredytu, to nie następuje to w relacji JST - leasingodawca, JST - sprzedawca, a w relacji np. instytucja finansowa - leasingodawca, instytucja finansowa - sprzedawca. Świadczenia, do których zobowiązuje się JST na podstawie tych umów nie są związane ze spłatą pozyskanych środków finansowych, nie wpisują się we właściwą dla pożyczek, kredytów, papierów wartościowych relację: przychody - rozchody. Wpływ środków z tytułu kredytu, pożyczki, obligacji jest, bowiem przychodem budżetu JST, spłata długu (zwrot środków) rozchodem budżetu. Tylko koszty pozyskania środków zwrotnych kwalifikowane są jako wydatki budżetu (prowizja, odsetki, itp.). W takich przypadkach określenie analizowanych umów, jako długu spłacanego wydatkami, ma swoje uzasadnienie. Problem w tym, że uzasadnienie to nie jest aktualne w stosunku do wszystkich zobowiązań objętych $₫ 3$ pkt 2 rozporządzenia. Jednostki samorządu terytorialnego korzystają, bowiem także z takich instrumentów finansowych, które pozwalają im pozyskać środki finansowe, z obowiązkiem ich zwrotu. Na podstawie stosowanych konstrukcji prawnych otrzymane środki kwalifikowane są, jako dochody budżetu (np. sprzedaż zwrotna, leasing zwrotny) lub w ogóle nie mają odzwierciedlenia w planie budżetu (np. subrogacja połączona z restrukturyzacją zobowiązań). Planowane w budżecie wydatki przeznaczone są de facto na zapłatę za udostępnienie kapitału, oraz na jego zwrot. Te zobowiązania mają zatem istotnie odmienny charakter od wcześniej wskazanych, a charakter wydatków z nimi związanych na płaszczyźnie ekonomicznej utożsamia je z umowami pożyczek lub kredytów. Zawarte $\mathrm{w} \$ 3$ pkt 2 rozporządzenia sformułowanie o skutkach ekonomicznych podobnych do umowy pożyczki lub kredytu nie jest tutaj adekwatne.

Niezależnie od powyższego jeszcze raz należy podkreślić, że spłata długu objętego $\$ 3$ pkt 2 rozporządzenia (poza papierami wartościowymi) nie jest uwzględniona w relacji ujętej w art. 243 ust. 1 ufp i brak jest normatywnych podstaw do ujmowania przedmiotowych wydatków (np. z ty- 
tułu umów nienazwanych o terminie zapłaty dłuższym niż rok, związanych z finansowaniem usług, dostaw, robót budowlanych, które wywołują skutki ekonomiczne podobne do umowy pożyczki lub kredytu) przy obliczaniu rocznego wskaźnika spłaty zobowiązań. Wszystkie, z wyjątkiem papierów wartościowych, przywołane powyżej tytuły dłużne spłacane są poprzez wydatki budżetu JST, a formuła zawarta w art. 243 ust. 1 ww. ustawy obejmuje wyłącznie wydatki z tytułu odsetek i dyskonta od zobowiązań zaciągniętych w sytuacjach opisanych w art. 89 ust. 1 i art. 90 ufp oraz potencjalne wydatki z tytułu udzielonych poręczeń i gwarancji. Pozostałe kwoty to rozchody (spłata rat kredytów, pożyczek, wykup obligacji). O ile w stanie prawnym obowiązującym do 31 grudnia 2013 r., tzw. dług spłacany wydatkami uwzględniany był przy obliczaniu wskaźnika zadłużenia JST, na podstawie art. 170 ustawy z 30 czerwca 2005 r. o finansach publicznych, to po 1 stycznia 2014 r. może mieć znaczenie przy budowaniu prawej strony relacji spłaty zobowiązań, jeżeli jego spłata powiększa kwotę wydatków bieżących. Nie ma to jednak znaczenia dla jednostki samorządowej korzystającej z takich instrumentów, bowiem maksymalny wskaźnik spłaty zobowiązań nie limituje przecież spłat związanych z przedmiotowymi umowami. Może być on nawet ujemny, a jednostka samorządowa może zawrzeć umowę nienazwaną związaną z finansowaniem usług, dostaw, robót budowlanych, mającą wszelkie cechy kredytu lub pożyczki, nie będąc jednak formalnie identyfikowana $\mathrm{z}$ takim zobowiązaniem. W skrajnym przypadku JST może mieć dług na poziomie np. ponad 150\% wykonanych dochodów, obciążający znacznie budżety kolejnych lat, a kwota rocznych spłat w ramach relacji ustalonej w art. 243 ufp wynosić będzie 0, bowiem wszystkie tytuły dłużne będą wynikały np. $z$ umów nienazwanych, czy też umów z ceną sprzedaży rozłożoną na raty.

Tym samym, maksymalny wskaźnik spłaty zobowiązań znajduje zastosowanie tylko do części długu. Jednostka samorządowa nie pokazując spłat zobowiązań dłużnych po lewej stronie relacji (wskaźnik roczny spłaty) może być jednak obciążona długiem w sposób zagrażający płynności finansowej.

\section{Wyłączenie z ograniczenia spłaty zobowiązań}

Ustawodawca limitując niektóre transfery z budżetu związane ze spłatą długu wyłączył z powyższego ograniczenia niektóre wydatki i rozchody. Stosownie do art. 243 ust. 3 i 3a ufp, przy obliczaniu przypadającej w danym roku kwoty spłat nie uwzględnia się (lewa strona relacji): 
1. Spłat kredytów i pożyczek zaciągniętych w związku z umową zawartą na realizację programu, projektu lub zadania finansowanego $\mathrm{z}$ udziałem środków, o których mowa w art. 5 ust. 1 pkt 2 ufp, wraz z należnymi odsetkami (art. 243 ust. 3 pkt 1 ufp);

2. Wykupów papierów wartościowych emitowanych w związku z umową zawartą na realizację programu, projektu lub zadania finansowanego $\mathrm{z}$ udziałem środków, o których mowa w art. 5 ust. 1 pkt 2 ww. ustawy wraz z należnymi odsetkami i dyskontem (art. 243 ust. 3 pkt 1a ufp);

3. Poręczeń i gwarancji udzielonych samorządowym osobom prawnym realizującym zadania JST $\mathrm{w}$ ramach programów finansowanych $\mathrm{z}$ udziałem środków, o których mowa w art. 5 ust. 1 pkt 2 ustawy o finansach publicznych (art. 243 ust. 3 pkt 2 ufp);

- w terminie nie dłuższym niż 90 dni po zakończeniu programu, projektu lub zadania i otrzymaniu refundacji z tych środków; termin ten nie ma zastosowania do odsetek i dyskonta od zobowiązań zaciągniętych na wkład krajowy, o których mowa w pkt 1 i 1a (część wspólna dla art. 243 ust. 3 ww. ustawy).

Ponadto w kwocie spłat nie uwzględnia się wykupów papierów wartościowych, spłat rat kredytów i pożyczek wraz z należnymi odsetkami i dyskontem, odpowiednio emitowanych lub zaciągniętych w związku $\mathrm{z}$ umową zawartą na realizację programu, projektu lub zadania finansowanego w co najmniej $60 \%$ ze środków, o których mowa w art. 5 ust. 1 pkt 2 ufp, w części odpowiadającej wydatkom na wkład krajowy, finansowanych tymi zobowiązaniami ${ }^{16}$.

Jeżeli, jak założyliśmy, relacja spłaty zobowiązań ma chronić bezpieczeństwo finansowe JST to wyłączenie spłat zobowiązań dłużnych, na które jednostka samorządowa nie otrzymuje środków zagranicznych (wkład krajowy) jest niezrozumiałe. Mając świadomość znaczenia procesów związanych z absorpcją środków europejskich, zadać należy jednak pytanie, o dobór instrumentów służących zwiększeniu efektywności tych procesów. W pierwszej kolejności powinny być to instrumenty realnie zwiększające potencjał ekonomiczny i finansowy JST, a nie wyłącznie formalne zabiegi pozostające bez związku z sytuacją finansową JST. Niestety zmiany w zakresie wyłączeń $z$ ograniczeń wynikających $\mathrm{z}$ relacji spłaty zobowiązań mieszczą się w kategorii działań o wymiarze formalnym.

16 W przypadku programu, projektu lub zadania przynoszącego dochód, poziom finansowania ze środków, o których mowa w art. 5 ust. 1 pkt 2 ww. ustawy, ustala się po odliczeniu zdyskontowanego dochodu obliczanego zgodnie z przepisami UE dotyczącymi takiego programu, projektu lub zadania. Kwotę wydatków na wkład krajowy ustala się w wysokości, jaka wynikałaby, gdyby poziom finansowania ze środków, o których mowa w art. 5 ust. 1 pkt 2 ustawy, obliczony został bez uwzględnienia zdyskontowanego dochodu (art. 243 ust. 3a ustawy). 
Bardzo szeroki zakres wyłączeń skutkuje sytuacją, w której zachowanie omawianej relacji wcale nie musi być koherentne z potencjałem ekonomicznym JST pozwalającym na dalsze zadłużanie się. Spłata zobowiązań finansujących publiczny wkład krajowy, w ramach realizacji projektów, programów lub zadań współfinasowanych ze środków, o których mowa w art. 5 ust. 1 pkt 2 ufp, podlega wyłączeniu przy obliczaniu rocznego wskaźnika spłaty zobowiązań (lewa strona relacji ustalonej w art. 243 ust. 1 ww. ustawy), stanowi jednak realne obciążenie budżetu, na które należy wygospodarować środki finansowe w odpowiedniej wysokości. Może to spowodować sytuację, w której JST zachowując omawianą relację, utraci płynność finansową, zaprzestając regulowania obciążających ją zobowiązań.

\section{Zachowanie relacji spłaty zobowiązań i znaczenie prognozy kwoty długu}

Spełnienie relacji wyznaczonej przez art. 243 ust. 1 ufp oznacza zatem tylko tyle, że według sformalizowanej reguły ustalonej przez ustawodawcę JST w danym roku jest w stanie spłacić część swojego długu (formalnie, ale już nie faktycznie). Wniosek ten nie dotyczy całości obciążającego jednostkę samorządową zadłużenia (przede wszystkim zobowiązania dłużne finansujące wkład krajowy oraz dług spłacany wydatkami). W konsekwencji wątpliwości budzi znaczenie prognozy długu w WPF, której celem jest w szczególności potwierdzenie zachowania omawianej relacji przez okres, na jaki uchwalono prognozę. Jeżeli ww. relacja ma stanowić formalnie ustalony wskaźnik potencjału finansowego JST, w kontekście obowiązku spłaty zadłużenia, to jej fragmentaryczny charakter czyni ten wskaźnik w niewielkim stopniu przydatnym dla przedstawionego celu. Wobec powyższego, przytoczona powyżej funkcja prognozy długu także ma ograniczone walory, a jej wypełnienie w coraz mniejszym stopniu zachowuje związek z faktyczną sytuacją finansową JST. Dodając do tego liczne wątpliwości dotyczące konstrukcji normatywnej wynikającej z przepisów art. 243 ufp, artykułowane w stosunku do ustawodawcy oczekiwanie zmian w zakresie ww. unormowań jest co najmniej uzasadnione. Na potrzebę tych zmian zwróciła uwagę Krajowa Rada RIO w Informacji dotyczącej przeprowadzonej w 2013 roku koordynowanej kontroli zadłużenia ${ }^{17}$

17 Zadłużenie jednostek samorzadu terytorialnego. Przestrzeganie ustawowych limitów zadłużenia i jego spłaty, Łódź 2014 r., www.bip.lodz.rio.gov.pl, (dostęp 10.06.2015 r.). 
oraz Najwyższa Izba Kontroli przy okazji kontroli odnoszącej się do wykonywania przez RIO zadań w zakresie przeciwdziałania zagrożeniom wynikającym $z$ nadmiernego zadłużania się JST ${ }^{18}$. Zmiana rozważanych regulacji normatywnych, uwzględniająca formułowane nie tylko przez organy kontroli i nadzoru postulaty ${ }^{19}$, w znaczący sposób wpłynie na ocenę WPF, jako dokumentu projektującego sytuację finansową JST, uwzględniającego całokształt operacji finansowych związanych z zaciąganiem długu i jego spłatą. Aktualnie, prognoza długu zbudowana wokół relacji spłaty zobowiązań, będąca jedną z kluczowych części WPF, przyczynia się do coraz intensywniejszej krytyki omawianej instytucji prawnej. Zamiast wszechstronnej analizy sytuacji finansowej JST, w szczególności związanej z długiem, WPF koncentruje się na wyselekcjonowanej przez ustawodawcę grupie zobowiązań, uznając - formalnie ustaloną - możliwość ich spłaty za kryterium decydujące o prawie JST do prowadzenia gospodarki finansowej w oparciu o budżet. Trudno jednocześnie znaleźć odpowiedź na pytanie, dlaczego sytuacji, w której uwzględnienie w relacji spłaty zobowiązań kwot przypadających do zapłaty z tytułu umów nienazwanych, wywołujących skutki ekonomiczne podobne do umowy pożyczki lub kredytu, skutkuje przekroczeniem maksymalnego wskaźnika spłaty zobowiązań, ustawodawca nie uznał za negatywną przesłankę uchwalenia budżetu JST. Skoro zobowiązania te zostały zrównane przez prawodawcę z kredytami i pożyczkami (patrz $\$ 3$ pkt 2 rozporządzenia Ministra Finansów w sprawie szczegółowego sposobu klasyfikacji tytułów dłużnych zaliczanych do państwowego długu publicznego), w konsekwencji powinny zostać uwzględnione w art. 243 ust. 1 ufp oraz w WPF (prognozie kwoty długu i jego spłaty).

Pilną potrzebą jest, zatem zidentyfikowanie podstawowego znaczenia prognozy długu i tym samym WPF, co wymaga istotnych zmian legislacyjnych. Obecnie funkcja ta nie jest jasna zarówno dla ustawodawcy, jak również dla JST, dla których WPF jest bardziej wymogiem formalnym, niż podstawą zarządzania strategicznego finansami lokalnymi ${ }^{20}$.

18 Informacja o wynikach kontroli Nr ewid. 18/2015/14/066/LBl, www.nik.gov.pl, (dostęp 10.06.2015 r.).

19 Zob. M Jastrzębska, Regulacje prawne w zakresie zaciaggania i obsługi długu przez jednostki samorzadu terytorialnego w Polsce - zalety i wady, [w:] Zadłużenie jednostek..., red. P. Walczak.

20 Zob. J.M. Salachna, Dlaczego należy poprawić mechanizmy wieloletniej prognozy finansowej, „Finanse Komunalne” 2015, nr 1-2, s. 67. 


\section{Realistyczność wieloletniej prognozy finansowej}

Wieloletnia prognoza finansowa nie będzie spełniać nawet tej zupełnie ograniczonej funkcji, jeżeli przy jej uchwalaniu naruszony zostanie prawnie istotny wymóg jej realistyczności. Zupełnie niespodziewanie istotne utrudnienia w tym zakresie przyniosło orzecznictwo sądów administracyjnych.

Cecha realistyczności WPF jest elementem dyspozycji normy prawnej budowanej w oparciu o art. 226 ufp. Mimo braku wyrazistego znaczenia przedmiotowego pojęcia, nie powinno ulegać wątpliwości, że spełnienie wymogu sformułowanego przez ustawodawcę warunkuje uznanie prognozy za zgodną z przepisami. Właściwe do takiej oceny są kolegia RIO, jako organy nadzoru w zakresie uchwał w sprawie WPF. Badanie legalności przedmiotowej uchwały zakłada również weryfikację odnoszącą się do jej realistyczności, czyli rozstrzygnięcie, czy treść prognozy odpowiada wzorcowi normatywnemu utworzonemu na podstawie art. 226 ust. 1 ww. ustawy. Negatywna ocena tej okoliczności winna skutkować podjęciem rozstrzygnięcia nadzorczego. Szereg orzeczeń RIO stwierdzających nieważność uchwały w sprawie WPF ma u swej podstawy wniosek stwierdzający brak realistyczności prognozy, a samodzielną podstawą rozstrzygnięcia jest naruszenie art. 226 ust. 1 ufp.

W tym kontekście interesujące są wyroki WSA w Szczecinie (wyrok WSA w Szczecinie z 28.11.2013 r., sygn. I SA/Sz 1129/13 ${ }^{21}$ ) i WSA w Warszawie (wyrok WSA w Warszawie z 11.3.2014 r., sygn. V SA/Wa 262/1422), w których sądy zakwestionowały art. 226 ust. 1 ustawy o finansach publicznych, w zakresie cechy realistyczności, jako samodzielny wzorzec normatywny rozstrzygnięcia nadzorczego. W konsekwencji sądy zgodnie przyjęły, że przesłanka realizmu WPF, o której mowa w art. 226 ust. 1 ustawy, adresowana jest przede wszystkim do JST, co oznacza, że wykazanie przez RIO naruszenia tego przepisu musi być powiązane z naruszeniem innego przepisu prawa, np. art. 243 ufp.

Tezy powyższe są bardzo kontrowersyjne, jeżeli nie zupełnie błędne. Po pierwsze, naruszenie art. 243 ufp stanowi samodzielną przesłankę stwierdzenia istotnego naruszenia prawa w przypadku WPF i w żaden sposób nie wymaga w swej kwalifikacji uzupełnienia przez art. 226 ustawy. Po drugie, większość norm określających standardy prowadzenia gospodarki finansowej adresowana jest do JST, np. wymóg pokazania w uchwale

21 Centralna Baza Orzeczeń Sądów Administracyjnych.

22 Centralna Baza Orzeczeń Sądów Administracyjnych. 
budżetowej źródeł sfinansowania deficytu budżetu, czy też uchwalenia WPF na stosowny okres. Zadaniem organu nadzoru jest stwierdzenie, czy JST wymogi te spełniła. Taka też sytuacja zachodzi w przypadku dyspozycji wynikającej z art. 226 ww. ustawy. Bez wątpienia adresatem normy jest organ stanowiący JST, ale okoliczność, czy wzorzec normatywny został w danej sytuacji zachowany bada organ nadzoru (kolegium RIO). Etapem tego badania jest ustalenie znaczenia normy prawnej, a w szczególności pojęcia „realistyczności”. Mając powyższe na względzie, uzasadniony jest pogląd, że sądy w sposób nieuprawniony ograniczyły w swych orzeczeniach kompetencje nadzorcze $\mathrm{RIO}^{23}$.

Mimo znaczących trudności związanych z wyinterpretowaniem znaczenia normy prawnej wprowadzającej wymóg realistyczności prognozy, jest to jedna $\mathrm{z}$ istotniejszych jej cech normatywnych, pozwalająca rozważać w przyszłości WPF jako realny instrument zarzadzania finansami lokalnymi.

\section{Podsumowanie}

Wieloletnia prognoza finansowa funkcjonuje w określonym otoczeniu normatywnym, a na jej ocenę wpływają w największym stopniu przepisy normujące relację spłaty zobowiązań. Słabości i wady wskazanej konstrukcji bezpośrednio rzutują na WPF, w tym na prognozę kwoty długu. Czyniąc przedmiotową relację osią prognozy, ustawodawca pominął w konsekwencji część długu, a poprzez wyłączenie z omawianego ograniczenia spłat dotyczących wielu tytułów dłużnych, jeszcze bardziej zawęził zakres przedmiotowy relacji, jak również prognozy długu i jego spłaty. Uwarunkowania te, szczegółowo omówione powyżej, uniemożliwiają postrzeganie WPF, jako skutecznego instrumentu zarządzania długiem JST. Sytuację komplikują dodatkowo spory wokół sposobu rozumienia wymogu realistyczności i zakresu ingerencji nadzorczej ze strony RIO. Zmiana tej sytuacji wymaga daleko idących modyfikacji obowiązujących przepisów, nie tylko tych regulujących instytucję WPF. Bez wątpienia obecny poziom zadłużenia JST, jak również perspektywa przyrastania

23 Zob. też G. Wróblewska, op. cit., s. 103; J.M. Salachna, s. 66; odmiennie S. Srocki, op. cit., s. 10-12, który ogranicza badanie realistyczności WPF do oceny zgodności wartości przyjętych w WPF z budżetem i danymi dotyczącymi wielkości wcześniej zaciągniętych zobowiązań dłużnych oraz J.M. Salachna, op. cit., s. 33-34, która stwierdza, że ocena realności WPF prowadziłaby do uznania, że RIO podejmują decyzje merytoryczne w zakresie gospodarki finansowej JST. 
długu związana z pozyskiwaniem środków z budżetu UE, sprawia iż wypracowanie instrumentów pozwalających skutecznie zarządzać długiem jest bardzo potrzebne.

\section{Bibliografia}

Finanse publiczne. Praktyka stosowania nowej ustawy o finansach publicznych i aktów wykonawczych, red. Lachiewicz W., Warszawa 2010.

Informacja o wynikach kontroli NIK. Nr ewid. 18/2015/14/066/LBI.

Srocki, Wieloletnia prognoza finansowa jako instrument stabilizacji finansowej samorzadu - zagadnienia prawne, „Finanse Komunalne” 2014, nr 12.

Salachna J.M., Budżet $i$ wieloletnia prognoza finansowa jednostek samorządu terytorialnego. Od projektu do sprawozdania, Gdańsk 2010.

Salachna J.M., Dlaczego należy poprawić mechanizmy wieloletniej prognozy finansowej, „Finanse Komunalne” 2015, nr 1-2.

Sprawozdanie z działalności regionalnych izb obrachunkowych i wykonania budżetu przez jednostki samorządu terytorialnego w 2007 r., Warszawa 2008.
Sprawozdanie z działalności regionalnych izb obrachunkowych i wykonania budżetu przez jednostki samorządu terytorialnego w 2009 r., Warszawa 2010.

Sprawozdanie z działalności regionalnych izb obrachunkowych i wykonania budżetu przez jednostki samorządu terytorialnego w 2014 r., Warszawa 2015.

Wróblewska G., Zarządzanie długiem jednostki samorzqdu terytorialnego - problemy praktyczne, „Finanse Komunalne" 2015, nr 1-2.

Zadłużenie jednostek samorzadu terytorialnego. Przestrzeganie ustawowych limitów zadłużenia i jego spłaty, Łódź 2014.

Zadłużenie jednostek samorządu terytorialnego. Wyzwania w obliczu nowej perspektywy finansowej UE, red. Walczak P., Warszawa. 